\title{
UJI BIOAKTIVITAS DAN PENELURUSAN METABOLIT SEKUNDER EKSTRAK SPONS DI PERAIRAN KAMPUNG MALAHING KOTA BONTANG
}

\author{
Choirun Nisa*, Muhammad Amir Masruhim, Riski Sulistiarini \\ ${ }^{1}$ Laboratorium Penelitian dan Pengembangan FARMAKA TROPIS Fakultas \\ FarmasiUniversitas Mulawarman, Samarinda, Kalimantan Timur \\ *Email: $\underline{\text { Cnisaaa@gmail.com }}$
}

\begin{abstract}
Sponges are multicellular animals of the porifera phylum and a marine invertebrates that live in the coral reef ecosystem that causes these animals do not migrate. To defend themselves from predators and pathogens of bacterial infections, sponges develop biodefense system by delivering toxic substances from the body, this substance can generally be used as pharmaceuticals compond. This study was identify a secondary metabolite and bioactivity test of two species of sponges which collected from kampung malahing, Bontang city, east Kalimantan. This study was aimed to identification the secondary metabolites and screening their toxicity of the chemical compounds. Sample extraction procedure was performed by using maceration for 5 days and evaporated. Sample extract was indentified of their secondary metabolite and tested using Brine Shrimp lethality Test (BSLT) method. This study performed of sponge yielded alkaloid and karotenoid which showed $L C_{50} 313,13$ ppm.
\end{abstract}

Keywords : Sponges, bioactivity, Brine Shrimp Lethality Test, $\mathrm{LC}_{50}$.

\begin{abstract}
ABSTRAK
Spons merupakan hewan multiseluler dari filum porifera dan merupakan invertebrata laut yang hidup pada ekosistem terumbu karang yang menyebabkan hewan ini tidak berpindah tempat. Untuk mempertahankan diri dari serangan predator dan infeksi bakteri pathogen, spons mengembangkan system biodefense yaitu dengan menghasilkan zat racun dari dalam tubuhnya, zat ini umumnya dapat dimanfaatkan sebagai bahan farmasi. Pada penelitian ini telah dilakukan uji bioaktivitas dan penelusuran metabolit sekunder pada dua jenis spons diperairan kampung malahing Kota Bontang, Kalimantan Timur. Penelitian ini bertujuan untuk mengidentifikasi metabolit sekunder dan skrining toksisitas senyawa kimia. Prosedur ekstraksi sampel menggunakan metode maserasi dengan pelarut metanol selama 5 hari dan diganti pelarut setiap hari. kemudian di evaporasi. Lalu sampel spons di uji kandungan metabolit sekunder dan uji 50\% kematian pada hewan uji larva udang Artemia salina Leach. Hasil penelitian pada jenis sampel spons menghasilkan senyawa golongan alkaloid dan karotenoid dengan nilai $\mathrm{LC}_{50} 313,13$ ppm.
\end{abstract}

Kata Kunci : Spons laut, bioaktivitas, Brine Shrimp Lethality Test, $\mathrm{LC}_{50}$. 


\section{PENDAHULUAN}

Indonesia merupakan Negara kepulauan terbesar di dunia, yang terletak di kawasan tropis dan merupakan salah satu Negara dengan keanekaragaman hayati laut tertinggi (megabiodiversity), salah satunya adalah spons. Menurut Sujatmiko (2000) jumlah spesies spons di Indonesia diperkirakan sebanyak 830 spesies. Dengan banyaknya spesies spons tersebut semakin besar peluang untuk ditemukannya senyawa-senyawa bioaktif. Spons mensintesis metabolit sekunder (senyawa bioaktif) yang bersifat toksik untuk alat pertahanan diri melawan bakteri, fungi, dan virus. Salah satu toksin tersebut adalah Asam okadaik (ocadaic acid) yang dihasilkan oleh spons hitam jenis Halichondria okadoi kadota. Selain itu, lebih dari 500 metabolit telah diisolasi dari spons. Beberapa dari metabolit ini memiliki struktur yang unik dengan aktivitas biologi yang menarik, diantaranya yaitu antivirus, antifungi, antibiotik dan antimikroba (Bhakuni, 2005), Namun permasalahannya adalah belum banyak penelitian tentang produk laut ini.

Pemanfaatan spons dalam bidang kelautan bermanfaat sebagai indikator biologi untuk pemantauan pencemaran laut dan sebagai hewan penting untuk akuarium laut (Amir, 1996). Di dunia farmasi spons laut berpotensi sebagai obat. Berdasarkan penelitian Suriani et al (2012) spons Callyspongia sp. mengandung senyawa yang sangat toksik terhadap larva udang Artemia salina Leach. Spons laut di perairan kampung malahing kota Bontang hanya sebatas hewan laut dan belum dimanfaatkan. Berdasarkan wawancara dengan penduduk setempat, hal ini dikarenakan masyarakat tidak mengetahui manfaat dari spons laut, sehingga masyarakat tersebut lebih memanfaatkan produk laut lainnya yang telah diketahui manfaatnya. Produk laut yang dimanfaatkan masyarakat setempat sebagian besar adalah rumput laut dan ikan-ikan yang diolah menjadi ikan asin.

Berdasarkan hal tersebut di atas, peneliti ingin menguji toksisitas hewan laut yaitu spons dengan berdasarkan nilai $\mathrm{LC}_{50}$. Uji toksisitas merupakan uji skrining awal untuk mengetahui tingkat keamanan bahan yang akan digunakan oleh manusia. Sehingga penelitian ini dapat memberikan informasi ilmiah serta dapat bernilai ekonomis bagi masyarakat kota Bontang.

\section{METODE PENELITIAN}

Bahan

Bahan yang digunakan adalah spons laut diambil di perairan kampung malahing kota Bontang, tween 80, air laut, pelarut metanol, $\mathrm{HCl}$, pereaksi dragendorf, pereaksi mayer, Kalium iodida, merkuri(II)klorida, aquades, $\mathrm{CHCl}_{3}, \mathrm{H}_{2} \mathrm{SO}_{4}, \mathrm{FeCl}_{3}$, metanol 50\%, serbuk $\mathrm{Mg}, \mathrm{HCl}$ pekat, asam nitrat, bismut nitrat.

\section{Peralatan}

Alat yang digunakan adalah alat gelas, peralatan ekstraksi, peralatan uji Brine Shrimp Lethality Test (BSLT).

\section{Prosedur}

\section{Pengumpulan dan penyiapan sampel}

Sampel spons diambil diperairan kampung malahing di Kota Bontang dengan menggunakan kapal motor selama 15-20 menit, lalu diambil sampel dengan cara menyelam menggunakan peralatan scuba. Sampel yang telah didapat di cuci hingga bersih dengan air mengalir lalu disimpan pada wadah dan diberi es batu hingga sampel digunakan. Kemudian sampel di sortasi basah dan dipotong-potong menjadi ukuran yang lebih kecil, di keringkan dengan menggunakan oven suhu $50^{\circ} \mathrm{C}$ selama 3 jam. 


\section{Ekstraksi}

Sampel spons kering di masukkan kedalam wadah ekstraksi dan di maserasi menggunakan pelarut metanol selama 5 hari dan diganti pelarut setiap hari. Ekstrak hasil maserasi kemudian dipekatkan menggunakan rotary evaporator dan dilanjutkan dengan penguapan di waterbath hingga didapatkan ekstrak metanol spons.

\section{Pengujian metabolit sekunder}

Pengujian metabolit sekunder dengan cara diambil larutan ekstrak spons laut kemudian ditambahkan pereaksi. Uji alkaloid (pereaksi mayer, dragendorf, $\mathrm{HCl}$ ), uji karotenoid (pereaksi $\mathrm{CHCl}_{3}$ dan $\mathrm{H}_{2} \mathrm{SO}_{4}$ ), uji fenol (pereaksi $\mathrm{FeCl}_{3}$ ), uji flavanoid (pereaksi metanol 50\%, serbuk $\mathrm{Mg}, \mathrm{HCl}$ pekat), uji saponin (ditambahkan aquades), uji tanin (pereaksi $\mathrm{FeCl}_{3}$ ).

\section{Pengujian bioaktivitas}

Dibuat larutan stok 5000 ppm dengan menimbang 50 mg ekstrak spons dilarutkan dalam $10 \mathrm{~mL}$ air laut. Kemudian diambil konsentrasi uji (10 ppm, 50 ppm, 100 ppm, 500 ppm, 1000 ppm) dari larutan stok 5000 ppm. Dimasukkan kedalam vial berdasarkan konsentrasi uji, dibuat sebanyak 5 replikasi dan dibuat kontrol negatif. Dimasukkan 10 ekor larva udang dan 3 tetes pakan ragi, di tambahkan air laut hingga tanda batas $5 \mathrm{~mL}$. Diinkubasi selama 24 jam pada tempat yang dilengkapi lampu 5 watt. Setelah 24 jam diamati jumlah larva yang mati pada masing-masing vial. Berdasarkan hasil analisa probit sampel spons menghasilkan nilai $\mathrm{IC}_{50} 313,13 \mathrm{ppm}$.

\section{HASIL DAN PEMBAHASAN}

Sampel spons yang diambil diperairan kampung malahing kota Bontang,Pada tahap ekstraksi, digunakan 23 gram spons yang telah dikeringkan. Kemudian sampel diekstraksi menggunakan metanol selama 5 hari dan diganti pelarut setiap 24 jam. Hasil ekstraksi disaring menggunakan kertas saring, dan dipekatkan menggunakan alat rotary evaporator, kemudian di uapkan hingga didapatkan ekstrak kental. sebanyak 2,2 g (9,56\%). Metode pengujian aktivitas digunakan dalam penelitian ini adalah metode uji BSLT (Brine Shrimp Lethality Test). BSLT merupakan salah satu metode untuk menguji bahan-bahan yang bersifat aktif. Uji larva udang ini juga dapat digunakan untuk skrining awal senyawasenyawa yang diduga berkhasiat sebagai antitumor. Dilaporkan uji ini mempunyai korelasi yang positif dengan potensinya sebagai antitumor (Fajarningsih et al., 2008)

Pengujian bioaktivitas dilakukan dengan berbagai tingkat konsentrasi yaitu $50 \mathrm{ppm}$, 100 ppm, 500 ppm, dan 1000 ppm. Pengujian bioaktivitas terhadap larva udang Artemia salina Leach dilakukan sebanyak 5 replikasi pada masing-masing seri konsentrasi dan kontrol negatif yang digunakan. Hasil uji tersebut dapat dilihat pada tabel 1 berikut :

Tabel 1 Perhitungan analisa probit

\begin{tabular}{cccccc}
\hline \multirow{2}{*}{ Replikasi sampel } & \multicolumn{5}{c}{ Jumlah larva yang mati } \\
\cline { 2 - 6 } & $50 \mathrm{ppm}$ & $100 \mathrm{ppm}$ & $500 \mathrm{ppm}$ & $1000 \mathrm{ppm}$ & kontrol \\
\hline 1 & 3 & 2 & 10 & 10 & 0 \\
2 & 2 & 4 & 9 & 9 & 0 \\
3 & 1 & 2 & 9 & 9 & 0 \\
4 & 0 & 1 & 9 & 5 & 0 \\
5 & 1 & 4 & 10 & 7 & 0 \\
\hline Total Kematian & 7 & 13 & 47 & 40 & 0 \\
\hline
\end{tabular}




\begin{tabular}{cccccc}
\hline$\%$ Kematian & $14 \%$ & $26 \%$ & $94 \%$ & $80 \%$ & - \\
Harga Probit & 3,9197 & 3,8250 & 5,8416 & 5,4289 & - \\
\hline
\end{tabular}

Berdasarkan perhitungan tabel diatas didapatkan nilai LC $_{50}$ sebesar 313,13 ppm. Hal ini dapat dikatakan bahwa ekstrak spons laut bersifat aktif. Ekstrak diakatakan aktif jika $\mathrm{LC}_{50}$ $<1000$ ppm, sedangkan untuk senyawa murni < 200 ppm (Meyer,1982).

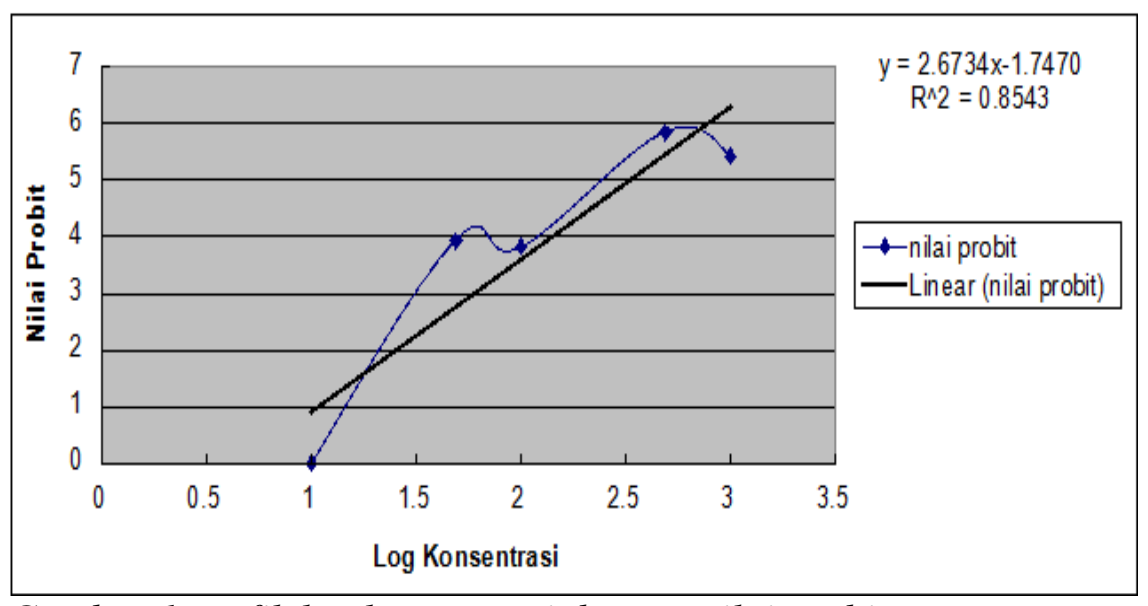

Gambar 1 grafik log konsentrasi dengan nilai probit.

Berdasarkan grafik diatas, semakin tinggi konsentrasi maka nilai probit akan semakin meningkat. Namun pada konsentrasi 1000 ppm terjadi penurunan nilai probit. Hal ini dikarenakan pada konsentrasi tersebut persen kematian larva udang menurun menjadi $80 \%$. Hal lainnya adalah ekstrak yang di uji merupakan ekstrak kasar dan belum di murninkan sehingga senyawa yang terkandung merupakan campuran senyawa yang kompleks. Sehingga aktivitas senyawa yang terkandung dapat bersifat antagonis yang menyebabkan terjadi penurunan persen kematian pada konsentrasi 1000 ppm.

Tabel 2 Uji senyawa metabolit sekunder sampel spons laut yang diambil di perairan kampung malahing kota Bontang

\begin{tabular}{cc}
\hline Uji metabolit sekunder & Hasil \\
\hline Alkaloid & + \\
Karotenoid & + \\
Fenol & - \\
flavanoid & - \\
Saponin & - \\
Tanin & - \\
\hline
\end{tabular}

Pada uji senyawa metabolit sekunder pada sampel spons laut didapatkan ekstrak mengandung senyawa alkaloid dan karotenoid. Karotenoid merupakan pigmen organik yang terdapat dalam suatu organisme. Organisme heterotrof, seperti hewan, juga memanfaatkan karotenoid dan memperolehnya dari makanan yang dikonsumsinya. Terdapat 2 kelompok besar karotenoid yaitu xantofil dan karotena. Peran terpenting karotenoid dalam proses fisiologi adalah sebagai zat antioksidan (Mithra, 2011). Dengan hal ini dapat dihubungkan dengan sifat karakteristik sampel, yang berwarna kuning. 


\section{KESIMPULAN}

Berdasarkan penelitian yang telah dilakukan maka dapat disimpulkan bahwa :

1. Berat rendemen yang didapat dari ekstrak spons laut adalah $9,56 \%$.

2. Sampel spons laut mengandung senyawa alkaloid dan karotenoid.

3. Sampel spons laut memiliki bioaktivitas terhadap larva udang Artemia salina Leach.

4. Nilai LC 50 yang didapatkan dari hasil pengujian bioaktivitas adalag 313,13 ppm.

\section{DAFTAR PUSTAKA}

1. Amir, I \& Budiyanto, A. 1996. Mengenal sponge laut (Demospongiae) secara umum. Oseana XXI Vol. 2 : Hal. 15-31.

2. Bhakuni, dan Rawat. 2005. Bioactive Marine Natural Product. Anamaya Publishers, New Delhi, India.

3. Fajarningsih, D.N., Januar, H.I., Wikanta, T., dan Nursid, M. 2008. Correlation between brine shrimp lethality test and cytotoxicity assay in marine natural products screening. Proceeding: International Seminar and workshop Marine Biodiversity and their potential for developing bio-pharmaceutical industry in Indonesia, Jakarta.

4. Meyer, B.N. 1982. Brine shrimp: a conventional general bioassay for active plants constituents. Plant Medica. 45: 31-34.

5. Sujatmiko, W. 2000. Inventarisasi Jenis Spons Disekitar Perairan Pulau Lombok dan Garam Di Pulau Sumbawa NusaTenggara Barat. Kerjasama : Yayasan Rinjani Bahari, Badan Pengkajian dan Penerapan Teknologi, Badan Perencanaan dan Pembangunan Propinsi Nusa Tenggara Barat.

6. Suriani, et al. 2012. Isolasi, Karakterisasi, dan Uji Bioaktifitas MetaboliSekunder dari Spons Callyspongia sp. Marina Chimica Acta, April 2012,hal Program Buginesia, Universitas Hasanuddin Vol. 12 No. 1 Hal.6. 